\title{
Pengembangan Alat Tempo Trainer untuk Membantu Efisiensi Gerakan Lengan Gaya Bebas Cabang Olahraga Renang
}

\author{
Bahtiyar Heru Susanto \\ Universitas Muhammadiyah Yogyakarta. Jalan Lingkar Selatan, Tamantirto, Bantul, 55183, Indonesia \\ Email: bahtiyar.heru22@gmail.com
}

Received: 13 October 2015; Revised: 26 September 2017; Accepted: 9 October 2017

\begin{abstract}
Abstrak
Penelitian ini bertujuan untuk mengembangkan alat tempo trainer untuk membantu efisiensi gerakan lengan gaya bebas pada cabang olahraga renang. Uji coba skala kecil dilakukan terhadap 4 pelatih dan 10 atlet di perkumpulan renang Tirta Alvita dan Yuso. Uji coba skala besar dilakukan terhadap 10 pelatih dan 25 atlet di perkumpulan renang Tirta Alvita, Yuso, Dolphin, Caesar, dan Arwana. Instrumen yang digunakan untuk mengumpulkan data adalah angket berdasarkan analisis PIECES (performance, information, economic, control, efficiency, service). Hasil penilaian ahli, pelatih, dan atlet terhadap alat tempo trainer menunjukkan bahwa penilaian berkategori baik, valid, dan reliabel. Berdasarkan hasil tersebut, alat tempo trainer yang dikembangkan dapat menghitung siklus gerakan lengan gaya bebas, bisa mengeluarkan suara yang didengar oleh pelatih dan atlet, bisa digunakan untuk lebih dari satu atlet, serta lebih terjangkau. Penilaian pelatih menunjukkan hasil valid dengan nilai rata-rata indikator PIECES memperoleh nilai $\mathrm{r}_{\mathrm{xy}}>\mathrm{r}$ tabel $=0,632$, reliabel dengan hasil nilai $r=0,908$. Penilaian draf alat tempo trainer oleh atlet berkategori baik, valid dengan nilai $r_{x y}>r$ tabel $=0,750$.
\end{abstract}

Kata Kunci: alat, tempo huruf kecil, rainer, efisiensi gerakan lengan gaya bebas

\section{Developing the Tool of Tempo Trainer to Help Efficiency of Arm Movement in the Freestyle on the Branch of Swimming}

\begin{abstract}
This research aimed to develop the tools of Tempo Trainer to help efficiency of arm freestyle movement on the branch of swimming. Small-scale trials were conducted on four coaches and 10 athletes in the swimming association Tirta Alvita and Yuso. Large-scale trial was conducted on 10 coaches and 25 athletes in the swimming association Tirta Alvita, Yuso, Dolphin, Caesar, and Arowana. The instrument used to collect data was a questionnaire based on the analysis PIECES (Performance, Information, Economic, Control, Efficiency, Services). The assessment result of experts, coaches, and athletes toward Tempo Trainer tool shows that the assessment categoryis good, valid and reliable. Based of the resultsthat Tempo Trainer tool developed can count the number of cycles of freestyle movement, a sound that can be heard by coaches and athletes, can be used for more than one athlete, as well as it is more affordable. The coaches assessment shows valid results with every indicator PIECES obtain value $r_{x y}>r$ table $=0.632$, with reliable results $r_{x y}=0.908$. The assessment of Tempo Trainer draft tool by athletes is good and valid with the result of the $r_{x y}>r$ table $=0.750$.
\end{abstract}

Keywords: tool, tempo trainer, efficiency freestyle arm movements

How to Cite: Susanto, B. (2017). Pengembangan alat tempo trainer untuk membantu efisiensi gerakan lengan gaya bebas cabang olahraga renang. Jurnal Keolahragaan, 5(2), 122-132.

doi:http://dx.doi.org/10.21831/jk.v5i2.5755

Permalink/DOI: http://dx.doi.org/10.21831/jk.v5i2.5755 


\section{Jurnal Keolahragaan 5 (2), September 2017 - 123}

Bahtiyar Heru Susanto

\section{PENDAHULUAN}

Falaahudin \& Sugiyanto (2013, p. 14) menyatakan bahwa berenang adalah gerakan sewaktu bergerak di air. Berenang biasanya dilakukan tanpa menggunakan alat bantu. Penentuan juara dalam perlombaan renang menggunakan acuan waktu. Fernandes, dkk. (Kolmogorov \& Duplishcheva, 1992), mengatakan "Performance in swimming is measured by the time that the swimmer needs to cover a specific distance." Waktu terbaik atlet renang sangat dipengaruhi oleh kecepatan, sehingga semakin cepat kecepatan berenang seorang atlet waktu yang diperlukan untuk menempuh jarak tertentu akan semakin singkat. Namun demikian, kecepatan saja tidak dapat menjamin seorang atlet renang dapat berprestasi dalam renang karena prestasi renang juga didukung oleh faktor-faktor lain. Hal tersebut sesuai dengan pendapat Mandzák \& Stankiewicz (2014, p. 27) yang menyatakan bahwa prestasi renang sangat dipengaruhi oleh faktor yang kompleks. Faktorfaktor tersebut memengaruhi kualitas kinerja perenang. Penelitian lain tentang renang (Mandzak et al., 2010, p.78) menyebutkan bahwa selain faktor somatik, biomotor, dan psikologis, terdapat faktor yang sangat penting yaitu teknik berenang.

Teknik yang benar akan menunjang gerak yang efisien. Apabila teknik yang dilakukan salah, gerakan renang yang dilakukan tidak akan efisien. Efisiensi gerakan berpengaruh terhadap waktu dan tenaga yang digunakan selama berenang. Semakin efisien gerakan bisa ditandai dengan waktu yang semakin singkat dan atau tenaga yang digunakan semakin sedikit.

Gerakan renang yang dihitung untuk mengetahui tingkat efisiensi gerakan adalah jumlah siklus untuk menyelesaikan jarak renangan. Salah satu siklus gerakan yang dapat dihitung adalah gerakan lengan gaya bebas. Smith (2012, p.31) menyatakan bahwa satu siklus gerakan lengan gaya bebas adalah satu kali gerakan lengan kanan penuh ditambah satu kali gerakan lengan kiri penuh sampai kembali ke posisi awal.

Cara menghitung siklus gerakan renang menyulitkan pelatih apabila jumlah atlet lebih dari satu, sehingga pelatih membutuhkan alat yang bisa digunakan untuk melatih efisiensi gerakan renang pada atlet pemula. Kriteria alat yang dibutuhkan pelatih adalah dapat menghitung siklus gerakan renang, suara dapat didengar pelatih maupun atlet, bisa digunakan lebih dari satu atlet, serta harga terjangkau.

\section{Efisiensi Gerakan Lengan Gaya Bebas}

Pencapaian prestasi renang dapat dicapai karena dipengaruhi oleh banyak faktor. Faktorfaktor tersebut di antaranya adalah bakat, kondisi fisik, komponen biomotor, teknik, dan efisiensi gerakan. Efisiensi gerakan renang menjadi faktor penting karena pencapaian prestasi renang diukur dengan waktu yang selalu berhubungan erat dengan kecepatan. Kecepatan berenang dapat dicapai karena gerakan yang dilakukan secara efisien.

Efisiensi dalam berenang dapat diukur dari waktu dan banyaknya gerakan untuk menempuh jarak tertentu. Hal yang sama dinyatakan oleh Hannula (2008, p. 44) bahwa melakukan dayungan secara efisien adalah mengenai menghitung dayungan. Menghitung jumlah dayungan untuk satu jarak kolam adalah metode yang lebih mudah dan efektif untuk memaksimalkan jarak per dayungan.

Gerakan lengan gaya bebas yang efisien akan menghasilkan kecepatan berenang. Kecepatan berenang gaya bebas dipengaruhi oleh dayungan lengan. Dayungan lengan (stroke) mempunyai dua unsur penting yang harus dipenuhi yaitu frekuensi dayungan (stroke rates) dan panjang dayungan (stroke lengths). Keduanya adalah satu rangkaian penuh gerakan lengan. Satu rangkaian lengan penuh dalam renang disebut dengan siklus.

Penelitian yang dilakukan Fernandes, dkk. (Kolmogorov \& Duplishcheva, 1992), menjelaskan bahwa prestasi dalam renang diukur dari waktu perenang untuk menempuh jarak tertentu. Usaha untuk mencapai dan mempertahankan kecepatan yang digunakan sangat bergantung pada parameter biomekanik dan fisiologis. Salah satu dari faktor biomekanik yaitu pengaruh dayungan (frekuensi dayungan dan panjang dayungan). Hannula (2008, p. 43) menyatakan bahwa kecepatan renang bergantung pada beberapa faktor yaitu panjang dayungan dan frekuensi dayungan. Frekuensi dayungan adalah banyaknya siklus kayuhan lengan dalam satu menit (siklus per menit) atau waktu untuk menyelesaikan satu siklus gerakan lengan (detik per siklus). Panjang dayungan adalah jarak yang dicapai dalam satu kali siklus gerakan lengan.

Frekuensi dayungan adalah banyaknya siklus kayuhan lengan dalam satu menit (siklus per menit) atau waktu untuk menyelesaikan satu siklus gerakan lengan (detik per siklus). Panjang 


\section{Jurnal Keolahragaan 5 (2), September 2017 - 124}

Bahtiyar Heru Susanto

dayungan adalah jarak yang dicapai dalam satu kali siklus gerakan lengan. Satu siklus gerakan lengan gaya bebas adalah satu kali gerakan lengan kanan penuh ditambah satu kali gerakan lengan kiri penuh sampai kembali ke posisi awal. Smith (2012, p.31) mengatakan gerakan dayungan yang baik seharusnya mencakup penghitungan siklus atau dayungan. Penghitungan ini harus digunakan untuk meng-urangi kebingungan perenang. Satu siklus untuk gaya punggung dan gaya bebas sama dengan dua dayungan lengan (kanan dan kiri), gaya kupukupu sama dengan satu gerakan tarikan penuh dan recovery, sedangkan gaya dada sama dengan satu gerakan tarikan lengan, recovery, dan satu gerakan kaki.

Frekuensi dayungan dan panjang dayungan harus berkombinasi dengan tepat agar kecepatan yang dihasilkan bisa maksimal. Seorang atlet bisa berenang dengan cepat pada saat terjadi kombinasi yang optimal antara panjang dayungan dan frekuensi dayungan, sedangkan apabila hanya salah satu saja dalam kondisi maksimal tidak menghasilkan renang yang cepat. Laughlin (2001, p. 15) menyatakan bahwa kecepatan adalah panjang dayungan dikalikan frekuensi dayungan. Hal tersebut adalah kunci keberhasilan perenang untuk mencapai kecepatan maksimal.

Craig dan Pendergast (Maglischo, 2003, p. 698) menyatakan bahwa hubungan antara frekuensi dayungan, panjang dayungan, dan kecepatan berenang sangatlah kompleks. Salah satu hubungan antara ketiganya merupakan hubungan yang negatif yaitu hubungan yang berbanding terbalik. Artinya, apabila panjang dayungan perenang dikurangi frekuensi dayungan bisa ditingkatkan, begitu pula sebaliknya. Pernyataan tersebut dikuatkan oleh pendapat (Greco, Pelarigo, Figueira, \& Denadai (2007, p. 441) yang menyatakan bahwa panjang dayungan dan frekuensi dayungan mempunyai hubungan yang tidak sebanding, artinya semakin panjang dayungan akan memungkinkan frekuensi dayungannya menjadi lambat. Begitu pula sebaliknya, semakin cepat frekuensi dayungan akan memungkinkan panjang dayungannya menjadi semakin pendek.

Dalam renang gaya bebas panjang dayungan dan frekuensi dayungan berkombinasi sebaik mungkin untuk memperoleh kecepatan yang maksimal. Hubungan antara kecepatan, panjang dayungan, dan frekuensi dayungan dalam renang gaya bebas dapat digambarkan dengan Gambar 1.

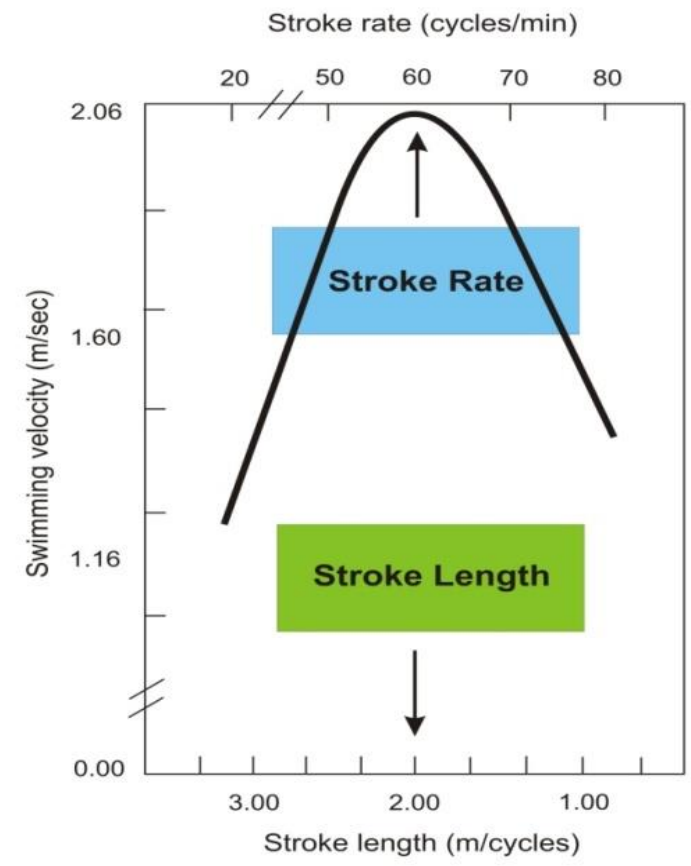

Gambar 1. Hubungan antara Kecepatan, Frekuensi Dayungan, dan Panjang Dayungan (Maglischo, 2003, p. 699)

Frekuensi dayungan dan panjang dayungan lengan pada gaya bebas berkombinasi untuk mendapatkan efisiensi gerakan maksimal. Kombinasi yang tepat antara frekuensi dayungan dan panjang dayungan akan menghasilkan daya dorong maksimal untuk mendukung kecepatan berenang. Maglischo (2003, p. 701) mengatakan bahwa ukuran kombinasi antara panjang dayungan dan frekuensi dayungan dapat ditunjukkan dalam Tabel 1.

Tabel 1. Ukuran Rata-rata antara Frekuensi Dayungan untuk Atlet Putra dan Putri dalam Kompetisi Renang Dunia

\begin{tabular}{lcc}
\hline \multirow{2}{*}{\multicolumn{1}{c}{ Events }} & \multicolumn{2}{c}{ Stroke Rates (cycles/min) } \\
\cline { 2 - 3 } & Men & Women \\
\hline 50 freestyle & $56-67$ & $60-65$ \\
100 freestyle & $50-56$ & $53-56$ \\
200 freestyle & $43-51$ & $48-54$ \\
400/500 freestyle & $38-46$ & $42-55$ \\
800/1000 freestyle & NA & $44-54$ \\
$1.500 / 1.650$ freestyle & $39-43$ & NA \\
\hline
\end{tabular}

Tabel 2. Ukuran Rata-Rata antara Panjang Dayungan untuk Atlet Putra dan Putri dalam Kompetisi Renang Dunia

\begin{tabular}{lcc}
\hline \multirow{2}{*}{ Events } & \multicolumn{2}{c}{ Stroke Lengths in $($ m/cycle $)$} \\
\cline { 2 - 3 } & Men & Women \\
\hline 50 freestyle & $1,88-2,16$ & $1,79-1,96$ \\
100 freestyle & $2,17-2,50$ & $1,80-2,05$ \\
200 freestyle & $2,25-2,41$ & $2,10-2,20$ \\
400/500 freestyle & $2,20-2,60$ & $1,75-2,20$ \\
\hline
\end{tabular}




\begin{tabular}{|c|c|c|}
\hline $800 / 1000$ freestyle & NA & $1,75-2,10$ \\
\hline $1.500 / 1.650$ freestyle & $2,26-2,53$ & NA \\
\hline
\end{tabular}
bebas yang dilakukan dengan terus-menerus mengurangi jumlah dayungan per panjang kolam sehingga akan memaksimalkan jarak per dayungan, tetapi pada akhirnya mengurangi efisiensi dayungan. Langkah selanjutnya dalam mengoptimalkan jarak per dayungan adalah latihan dengan target nilai terendah. Dalam hal ini, atlet berenang pada jarak yang telah ditentukan, sebagai contoh berenang dengan jarak 50 meter kemudian dihitung jumlah dayungan yang dilakukan serta dicatat waktu tempuhnya.

Berenang dengan target nilai terendah dirancang untuk menyamakan pembagian waktu kecepatan lomba dengan jumlah dayungan yang paling efisien. Sebagai contoh, seorang perenang dengan jarak 50 meter memerlukan waktu 30 detik dan 31 dayungan untuk menyelesaikan jarak tersebut, itu berarti jumlah nilai total sebesar 61. Jika perenang yang sama menyelesaikan 50 meter pada kesempatan selanjutnya dengan waktu 29,5 detik dan 33 dayungan, total nilainya adalah 62,5. Dalam kasus ini nilai 61 adalah renang yang lebih efisien dibandingkan dengan nilai 62,5. Saat perenang mencapai total nilai yang lebih rendah target nilai harus dikurangi untuk mencapai dayungan yang lebih efisien lagi.

\section{Latihan}

Latihan didefinisikan sebagai suatu proses sistematis yang dilakukan dalam jangka waktu panjang, berulang-ulang, progresif, dan mempunyai tujuan untuk meningkatkan penampilan fisik. Latihan merupakan suatu proses perubahan ke arah lebih baik, yaitu untuk meningkatkan kualitas fisik, kemampuan fungsional peralatan tubuh, dan kualitas psikis anak latih (Sukadiyanto \& Muluk, 2011, p. 1). Berdasarkan pengertian latihan tersebut dapat disimpulkan bahwa latihan adalah suatu proses yang dilakukan secara sistematis dalam waktu yang panjang, berulang-ulang, progresif serta mempunyai tujuan ke arah yang lebih baik untuk meningkatkan penampilan, kualitas fisik, fisiologis, dan psikologis anak latih.

Proses latihan yang dilakukan dari pelatih kepada atlet harus diprogram dengan baik. Program latihan hendaknya menerapkan prinsipprinsip dasar latihan guna mencapai kinerja fisik yang maksimal bagi seorang atlet. Prinsip latihan merupakan hal-hal yang harus ditaati, dilakukan atau dihindari agar tujuan latihan dapat tercapai sesuai dengan yang diharapkan (Sukadiyanto \& Muluk, 2011, p. 18). Prinsipprinsip dasar latihan yang secara umum harus diperhatikan adalah sebagai berikut:

\section{Prinsip Variasi}

Proses latihan dilakukan secara terusmenerus dan memerlukan waktu yang panjang sehingga dibutuhkan bentuk latihan yang bervariasi agar tidak terjadi kejenuhan yang disebabkan latihan yang monoton. Dalam hal ini pelatih dituntut untuk lebih kreatif dalam menyusun program latihan agar bervariasi.

\section{Prinsip Beban Berlebih (Overload)}

Suharjana (2007, p. 88) menyatakan bahwa prinsip beban berlebih pada dasarnya menekankan beban kerja yang dijalani harus melebihi kemampuan yang dimiliki oleh seseorang, karena itu latihan harus mencapai ambang rangsang. Berdasarkan pernyataan tersebut beban latihan yang dilakukan harus selalu meningkat secara bertahap.

\section{Prinsip Latihan Beraturan (Arrangement)}

Suharjana (2007, p. 23) mengatakan bahwa program latihan beban harus dibuat dengan baik, agar kelompok otot besar dapat dilatih terlebih dahulu sebelum melatih kelompok otot yang kecil, sebab kelompok otot kecil lebih cepat lelah dibanding dengan kelompok otot besar. Prinsip ini juga menganjurkan agar tidak melatih kelompok otot yang sama secara terus-menerus tanpa memberikan waktu yang cukup untuk pulih asal (recovery), sebab otot yang sedang mengalami kelelahan tidak akan dapat dilatih dengan baik.

\section{Prinsip Kekhususan (Specificity)}

Program latihan yang baik harus dipilih secara khusus sesuai dengan kebutuhan atau tujuan yang hendak dicapai (Irianto, 2004, p. 12). Dalam melakukan latihan, setiap bentuk rangsang akan direspons secara khusus oleh setiap orang atau olahragawan. Bentuk latihan yang diberikan sesuai dengan tujuan olahraga yang diinginkan, misalnya apabila akan meningkatkan kekuatan, program latihan harus memenuhi syarat untuk tujuan meningkatkan kekuatan.

\section{Prinsip Individual (Individuality)}

Bompa (1999, p. 35) menjelaskan bahwa latihan harus memperhatikan dan memperlaku- 


\section{Jurnal Keolahragaan 5 (2), September 2017 - 126}

Bahtiyar Heru Susanto

kan seseorang sesuai dengan kemampuan, potensi, karakteristik belajar, dan kekhususan olahraga.

\section{Prinsip Peningkatan secara Bertahap (Progresif)}

Beban kerja dalam latihan ditingkatkan secara bertahap dan disesuaikan dengan kemampuan fisiologis dan psikologis setiap individu olahragawan. Sukadiyanto \& Muluk (2011, p. 27) mengatakan bahwa, latihan bersifat progresif artinya dalam pelaksanaan latihan dilakukan dari yang mudah ke yang sukar, sederhana ke kompleks, umum ke khusus, sebagaian keseluruhan, ringan ke berat, dari kuantitas ke kualitas serta dilaksanakan secara ajeg, maju dan berkelanjutan.

\section{Prinsip Pulih Asal (Recovery)}

Pemulihan bertujuan untuk pengisian kembali pada kondisi sebelum berlatih, agar dapat menerima pembebanan yang lebih berat pada program pelatihan selanjutnya (Fox, Bowers, Foss, \& Fox, 1993, p. 692). Pada program latihan harus dicantumkan waktu pemulihan yang cukup, waktu pemulihan digunakan untuk mengurangi risiko over training akibat beratnya latihan.

\section{Mikrokontroler ATmega 8}

Adrianto (2008, pp.1-2) menyatakan bahwa mikrokontroler adalah sistem komputer yang seluruh atau sebagian besar elemennya dikemas dalam satu chip IC (intergrated circuit) sehingga sering juga disebut single chip microcomputer, yang masuk dalam katagori embedded komputer. Suatu mikrokontroler digunakan untuk mengontrol suatu proses atau aspek-aspek dari lingkungan. Mikrokontroler adalah suatu IC (intergrated circuit) dengan kepadatan yang sangat tinggi, di mana semua bagian yang diperlukan untuk suatu kontroler sudah dikemas dalam satu keping, biasanya terdiri atas CPU, RAM, EEPROM, I/O, TIMER, dan lain sebagainya (Winoto, 2010, p. 3).

\section{CPU (Central Processing Unit)}

CPU (central processing unit) merupakan bagian utama dalam sebuah mikrokontroler. Terdapat dua jenis CPU pada mikrokontroler yaitu CPU berukuran 8 bit dan CPU berukuran 16 bit. CPU ini akan membaca program yang tersimpan di dalam ROM (read only memory) dan melaksanakan perintah pada program tersebut.

\section{RAM (Random Acces Memory)}

RAM (random acces memory) adalah jenis memori yang selain dapat dibaca juga dapat ditulis berulang kali. Dalam pemakaian mikrokontroler terdapat semacam data yang bisa berubah pada saat mikrokontroler tersebut bekerja. Perubahan data tersebut tentunya juga akan tersimpan ke dalam memori.

\section{ROM (Read Only Memory)}

ROM (read only memory) adalah suatu memori (alat untuk mengingat) yang sifatnya hanya dibaca saja. ROM (read only memory) berfungsi menyimpan program pada mikrokontroler. Program yang tersimpan dalam format bilangan biner yaitu "0" atau "1". Susunan bilangan biner tersebut apabila telah terbaca oleh mikrokontroler akan memiliki arti tersendiri.

\section{Input/Output (I/O)}

Setiap mikrokontroler menggunakan terminal I/O (port I/O), yang digunakan untuk berkomunikasi dengan dunia luar. Bentuk komunikasi tersebut bisa dalam bentuk masukan atau keluaran.

\section{Komponen Lainnya}

Beberapa mikrokontroler memiliki timer/ counter, ADC (analog to digital converter), dan komponen lainnya. Pemilihan komponen tambahan yang sesuai dengan tugas mikrokontroler akan sangat membantu perancangan sehingga dapat mempertahankan ukuran yang kecil. Apabila komponen-komponen tersebut belum terdapat pada suatu mikrokontroler, pada umumnya komponen-komponen tersebut masih dapat ditambahkan pada sistem mikrokontroler melalui konektor-konektornya.

\section{METODE}

Penelitian ini menggunakan metode penelitian dan pengembangan (research and development) yang merupakan metode penelitian untuk menghasilkan produk tertentu, dan menguji keefektifan dari produk tersebut. Penelitian ini bertujuan untuk mengembangkan alat tempo trainer yang terbuat dari mikrokontroler untuk membantu latihan efisiensi gerakan lengan gaya bebas pada cabang olahraga renang. Mikrokontroler yang dikembangkan dapat menghitung siklus gerakan lengan gaya bebas, suara yang dihasilkan mikrokontroler dapat didengar pelatih maupun atlet pada saat berenang, dapat digunakan untuk lebih 


\section{Jurnal Keolahragaan 5 (2), September 2017 - 127}

Bahtiyar Heru Susanto

dari satu atlet, dan dengan harga yang terjangkau.

Prosedur penelitian dan pengembangan terdiri atas sepuluh tahapan pelaksanaan, yaitu: (1) studi pendahuluan dan pengumpulan data, (2) perencanaan, (3) mengembangkan produk awal, (4) uji coba produk awal, (5) revisi untuk menyusun produk utama, (6) uji coba lapangan utama, (7) revisi untuk menyusun produk operasional, (8) uji coba produk operasional, (9) revisi produk akhir, dan (10) diseminasi dan implementasi produk hasil pengembangan (Gall, Gall, \& Borg, 2007, p. 590). Tahapan penelitian dan pengembangan dalam penelitian ini mengacu pada tahapan tersebut namun lebih disederhanakan menjadi tujuh tahapan yaitu:

\section{Studi Pendahuluan dan Pengumpulan Data}

Dalam studi pendahuluan dilakukan analisis terhadap informasi dan data yang diperoleh melalui observasi di lapangan yaitu tentang proses latihan dan kebutuhan peralatan penunjang latihan khususnya yang berbasis elektronika di perkumpulan renang-perkumpulan renang di Daerah Istimewa Yogyakarta.

\section{Perencanaan}

Rencana penelitian yang dilakukan berupa penetapan alat, merumuskan tujuan dari penelitian yang dibuat, langkah-langkah dan solusi untuk menyelesaikan masalah, uji kelayakan produk, dan analisis keberhasilan produk yang dibuat.

\section{Mengembangkan Produk Awal}

Dalam mengembangkan produk awal, ada beberapa analisis terhadap alat yang akan dikembangkan di antaranya adalah:

\section{Analisis Pasar atau Ekonomi}

Analisis pasar yaitu untuk mengetahui kebutuhan pelatih renang terhadap alat yang akan dikembangkan yaitu tempo trainer. Pelatih butuh alat tersebut berdasarkan observasi lapangan yang dilakukan peneliti. Alat yang yang sudah ada yaitu finish tempo trainer pro memiliki beberapa kekurangan yang dapat ditutupi oleh alat tempo trainer yang dikembangkan.

\section{Analisis Psikologis}

Analisis ini dilakukan untuk mengetahui dampak psikologis yang ditimbulkan oleh tempo trainer terhadap atlet yang menggunakan alat tersebut. Kemungkinan gangguan yang ditimbulkan dari alat ini adalah suara yang tidak nyaman didengar sehingga mengganggu konsentrasi atlet pada saat latihan. Suara tersebut dapat dikontrol volumenya melalui speaker underwater sehingga dapat menghindari suara yang terlalu keras atau lemah.

Analisis Fisiologis

Analisis fisiologis dilakukan untuk mengetahui dampak yang ditimbulkan alat tempo trainer terhadap fisiologis atlet. Penggunaan tempo trainer dalam proses latihan diasumsikan dapat membantu meningkatkan kemampuan gerakan lengan atlet. Kemampuan tersebut berhubungan dengan efisiensi gerakan lengan, sehingga otot-otot lengan atlet akan bertambah kuat.

Analisis Ergonomis

Analisis ergonomis digunakan untuk menganalisis kinerja alat terhadap manusia yang menggunakannya dari segi keamanan dan kenyamanan. Dari segi keamanan, alat tempo trainer dapat dipastikan aman digunakan pelatih karena tidak berhubungan langsung dengan air jadi tidak mungkin terjadi korsleting listrik. Dari segi kenyamanan, baik pelatih maupun atlet akan nyaman dengan suara yang dihasilkan oleh tempo trainer karena suara dapat dikontrol volumenya sehingga tidak terlalu keras atau tidak terlalu lemah.

\section{Validasi Ahli dan Revisi}

Validasi merupakan proses untuk menilai rancangan produk secara rasional, logis, dan analitis. Validasi dalam penelitian ini dilakukan oleh ahli renang, ahli mikrokontroler, dan pelatih renang.

\section{Uji Coba Skala Kecil dan Revisi}

Uji coba produk merupakan kegiatan menguji produk yang dikembangkan kepada subjek yang dituju. Uji coba skala kecil dilakukan di dua perkumpulan renang.

\section{Uji Coba Skala Besar dan Revisi}

Uji coba skala besar dilakukan di lima perkumpulan renang. Pada pelaksanaan uji coba produk, dilakukan pengamatan oleh ahli untuk menilai kinerja produk yang dikembangkan.

\section{Produk Akhir}

Hasil penilaian yang dilakukan oleh para ahli dijadikan sebagai bahan masukan untuk memperbaiki alat yang telah dibuat. Setelah 
dilakukan revisi, kemudian dihasilkan produk akhir yang dapat diproduksi.

Penelitian ini dilaksanakan di klub renang atau perkumpulan renang yang resmi berada di bawah naungan PRSI dikarenakan telah memenuhi standar minimal jumlah atlet dan pelatih yang kompeten di bidangnya. Adapun perkumpulan renang tersebut adalah Yuso, Tirta Alvita, Dolphin, Arwana, Caesar, dan Shark Aquatik. Subjek penelitian adalah dua pelatih dan lima atlet pada tiap-tiap perkumpulan renang. Waktu penelitian berlangsung pada bulan Mei sampai dengan bulan Juni 2015.

Variabel dalam penelitian ini adalah variabel bebas dan variabel terikat. Alat tempo trainer sebagai variabel bebas, dan efisiensi gerakan lengan sebagai variabel terikat. Fokus penelitian ini adalah untuk mengembangkan alat yang dapat membantu efisiensi gerakan lengan gaya bebas.

Teknik pengumpulan data terdiri atas angket, dan lembar observasi (pengamatan) untuk ahli renang, ahli mikrokontroler, pelatih renang serta atlet. Instrumen yang digunakan dalam menilai dan menganalisis kelayakan alat menggunakan prosedur analisis PIECES (performance, information, econimic, control, efficiency, services). Untuk mendapatkan informasi dari permasalahan yang akan digunakan untuk melakukan penilaian dari sebuah rancangan sistem atau produk dilakukan dengan analisis PIECES. Analisis PIECES dilakukan untuk menilai kinerja, informasi, ekonomi, kontrol, efisiensi, dan pelayanan (Al-Fatta, 2007, pp.5152). Adapun kisi-kisi intrumen yang digunakan dapat dilihat pada Tabel 3.

Tabel 3. Kisi-Kisi Angket Validasi Ahli Renang

\begin{tabular}{cccc}
\hline No. & Faktor & Nomor butir & Total Butir \\
\hline 1. & Performance & $1-4$ & 4 \\
2. & Information & $5-8$ & 4 \\
3. & Economy & $9-12$ & 4 \\
4. & Control & $13-16$ & 4 \\
5. & Efficiency & $17-20$ & 4 \\
6. & Services & $21-24$ & 4 \\
\hline
\end{tabular}

Tabel 4. Kisi-Kisi Angket Validasi Ahli Mikrokontroler

\begin{tabular}{cccc}
\hline No. & Faktor & Nomor butir & Total Butir \\
\hline 1. & Interface & $1-4$ & 4 \\
2. & Navigasi & $5-8$ & 4 \\
3. & Kehandalan & $9-12$ & 4 \\
\hline
\end{tabular}

Tabel 5. Kisi-Kisi Observasi Ahli dan Pelatih Renang

\begin{tabular}{cccc}
\hline No. & Faktor & Nomor butir & Total Butir \\
\hline 1. & Performance & $1-3$ & 3 \\
2. & Information & $4-6$ & 4 \\
3. & Economy & $7-8$ & 2 \\
4. & Control & $9-10$ & 2 \\
5. & Efficiency & $11-12$ & 2 \\
6. & Services & $13-14$ & 2 \\
\hline
\end{tabular}

Tabel 6. Kisi-Kisi Observasi Ahli Mikrokontroler

\begin{tabular}{cccc}
\hline No. & Faktor & Nomor butir & Total Butir \\
\hline 1. & Interface & $1-3$ & 3 \\
2. & Navigasi & $4-6$ & 3 \\
3. & Kehandalan & $7-9$ & 3 \\
\hline
\end{tabular}

Tabel 7. Kisi-Kisi Angket Atlet

\begin{tabular}{cccc}
\hline No. & Faktor & Nomor butir & Total Butir \\
\hline 1. & Performance & 1 & 1 \\
2. & Information & 2 & 1 \\
3. & Economy & 3 & 1 \\
4. & Control & 4 & 1 \\
5. & Efficiency & 5 & 1 \\
6. & Services & 6 & 1 \\
\hline
\end{tabular}

Analisis data adalah proses mencari dan menyusun secara sistematis data yang diperoleh dari hasil wawancara, catatan lapangan, dan data-data lain, sehingga dapat mudah dipahami, dan temuan tersebut dapat diinformasikan kepada pihak lain. Analisis data dilakukan dengan mengorganisasikan data, menjabarkan ke dalam unit-unit, melakukan sintesis, menyusun ke dalam pola, memilih yang penting dan yang akan dipelajari, dan membuat kesimpulan yang dapat disampaikan kepada orang lain (Sugiyono, 2010 , p. 244). Teknik analisis data dalam penelitian ini adalah uji kelayakan dan keefektifan draf alar tempo trainer yang dihasilkan dengan cara penilaian oleh ahli renang, ahli mikrokontroler, pelatih renang, dan atlet pada saat uji coba lapangan berlangsung.

Norma kategorisasi yang digunakan sesuai dengan ketentuan Azwar (2003, p. 109).

Tabel 8. Pedoman Konversi Nilai

\begin{tabular}{cc}
\hline Formula & Kategori \\
\hline$X<(\mu-1,0 \sigma)$ & Kurang \\
$(\mu-1,0 \sigma) \leq X<(\mu+1,0 \sigma)$ & Cukup \\
$(\mu+1,0 \sigma) \leq X$ & Baik/Efektif \\
\hline
\end{tabular}

Keterangan:

$\mathrm{X}=$ jumlah skor subjek

$\mu=$ mean ideal

$\sigma=$ standar devisiasi ideal

$=1 / 6[$ (jumlah item $\mathrm{x}$ skor tertinggi) - (jumlah

item x skor terendah)] 
Uji validitas dan uji reliabilitas draf alat tempo trainer dilakukan dengan menggunakan data kuesoner untuk responden pelatih dan responden atlet pada uji coba skala kecil maupun uji coba skala besar. Uji validitas dan uji reliabilitas dilakukan dengan menggunakan bantuan Microsoft Excell 2007.

\section{HASIL DAN PEMBAHASAN}

Uji coba lapangan alat tempo trainer baik skala kecil maupun skala besar dilaksanakan setelah mendapat validasi atau standar kelayakan dari ahli renang dan ahli mikrokontroler. Instrumen validasi draf awal tempo trainer oleh ahli renang maupun ahli mikrokontroler menggunakan instrumen angket. Adapun hasil dari penilaian validasi para ahli terhadap draf awal tempo trainer dapat dilihat Tabel 9.

Tabel 9. Penilaian Validasi oleh Ahli Renang

\begin{tabular}{clcc}
\hline \multirow{2}{*}{ No. } & \multirow{2}{*}{ Indikator } & \multicolumn{2}{c}{ Skor Penilaian } \\
\cline { 3 - 4 } & & Ahli 1 & Ahli 2 \\
\hline 1. & Performance & 19 & 19 \\
2. & Information & 19 & 20 \\
3. & Economic & 19 & 20 \\
4. & Control & 20 & 20 \\
5. & Efficiency & 20 & 20 \\
6. & Service & 20 & 19 \\
& Total nilai & 117 & 118 \\
& Rata-rata & \multicolumn{2}{c}{117,5} \\
\hline
\end{tabular}

Tabel 10. Kategorisasi Penilaian Validasi Ahli Renang

\begin{tabular}{ccc}
\hline Interval & Kategori & Total Skor \\
\hline$<56$ & Kurang & - \\
$\geq 56$ s.d $<88$ & Cukup & - \\
$\geq 88$ & Baik & 117,5 \\
\hline
\end{tabular}

Penilaian validasi draf awal tempo trainer oleh ahli renang menunjukkan bahwa total nilai yang diperoleh yaitu 117,5 terletak pada interval $\geq 88$ sehingga berkategori baik. Berdasarkan hasil penilaian tersebut, draf awal tempo trainer yang dikembangkan telah memenuhi persyaratan kelayakan untuk uji coba di lapangan.

Tabel 11. Penilaian Validasi oleh Ahli Mikrokontroler

\begin{tabular}{ccc}
\hline No. & Indikator & Skor Penilaian \\
\hline 1. & Interface & 24 \\
2. & Navigasi & 24 \\
3. & Kehandalan & 25 \\
& Total Nilai & 73 \\
\hline
\end{tabular}

Penilaian validasi draf awal tempo trainer oleh ahli mikrokontroler menunjukkan bahwa total nilai yang diperoleh yaitu 73 terletak pada interval $\geq 55$ sehingga berkategori baik. Ber- dasarkan hasil penilaian tersebut, draf awal tempo trainer yang dikembangkan telah memenuhi persyaratan kelayakan untuk uji coba di lapangan.

Tabel 12. Kategorisasi Penilaian Validasi Ahli Mikrokontroler

\begin{tabular}{ccc}
\hline Interval & Kategori & Total Skor \\
\hline$<35$ & Kurang & - \\
$\geq 35$ s.d $<55$ & Cukup & - \\
$\geq 55$ & Baik & 73 \\
\hline
\end{tabular}

Uji coba skala kecil dilakukan di perkumpulan renang Tirta Alvita dan Yuso dengan 4 pelatih dan 10 atlet. Data hasil uji coba skala kecil dapat dilihat Tabel 13.

Tabel 13. Penilaian Observasi Ahli Renang pada Uji Coba Skala Kecil

\begin{tabular}{ccc}
\hline Interval & Kategori & Total Skor \\
\hline$<32,66$ & Kurang & - \\
$\geq 32,66$ s.d $<51,33$ & Cukup & - \\
$\geq 51,33$ & Baik & 67,5 \\
\hline
\end{tabular}

Tabel penilaian observasi oleh ahli renang tersebut menunjukkan total nilai terletak pada interval $\geq 51,33$ sehingga berkategori baik. Berdasarkan penilaian tersebut, draf tempo trainer telah memenuhi persyaratan kelayakan untuk dilakukan uji coba skala besar.

Tabel 14. Penilaian Observasi Ahli Mikrokontroler pada Uji Coba Skala Kecil

\begin{tabular}{ccc}
\hline Interval & Kategori & Total Skor \\
\hline$<21$ & Kurang & - \\
$\geq 21$ s.d $<33$ & Cukup & - \\
$\geq 33$ & Baik & 43 \\
\hline
\end{tabular}

Tabel penilaian observasi ahli mikrokontroler pada uji coba skala kecil menunjukkan bahwa total nilai berkategori baik dan terletak pada interval $\geq 33$. Berdasarkan penilaian tersebut, draf tempo trainer telah memenuhi persyaratan kelayakan untuk dilakukan uji coba skala besar.

Tabel 15. Penilaian Observasi Pelatih pada Uji Coba Skala Kecil

\begin{tabular}{ccc}
\hline Interval & Kategori & Total Skor \\
\hline$<18,67$ & Kurang & - \\
$\geq 18,67 \mathrm{~s} . \mathrm{d}<37,33$ & Cukup & - \\
$\geq 37,33$ & Baik & 43 \\
\hline
\end{tabular}

Tabel penilaian observasi pelatih renang pada uji coba skala kecil menunjukkan bahwa total nilai yang diperoleh berkategaori baik dan terletak pada interval $\geq 37,33$.

Berdasarkan uji validitas dan reliabilitas menggunakan bantuan Microsoft Excell 2007, 
diperoleh hasil bahwa draf tempo trainer valid untuk digunakan dengan nilai $\mathrm{r}_{\mathrm{xy}}=0.985$, nilai ini lebih dari nilai $r$ tabel $=0.950$. Dari analisis uji reliabilitas diperoleh nilai $r_{x y}=1$, nilai ini lebih dari 0.60 , dengan demikian dinyatakan bahwa draf tempo trainer reliabel.

Berdasarkan penilaian pelatih renang pada uji coba skala kecil ditunjukkan bahwa alat tempo trainer berkategori baik, valid dan reliabel sehingga dapat dinyatakan memenuhi persyaratan kelayakan untuk melakukan uji coba skala besar.

Tabel 16. Penilaian Atlet pada Uji Coba Skala Kecil

\begin{tabular}{ccc}
\hline Interval & Kategori & Total Skor \\
\hline$<20$ & Kurang & - \\
$\geq 20 \mathrm{s.d}<40$ & Cukup & - \\
$\geq 40$ & Baik & 50 \\
\hline
\end{tabular}

Tabel penilaian atlet terhadap draf tempo trainer pada uji coba skala kecil menunjukkan bahwa total nilai yang diperoleh terletak pada interval $\geq 40$, sehingga berkategori baik.

Berdasarkan uji validitas dan reliabilitas menggunakan bantuan Microsoft Excell 2007, diperoleh hasil bahwa draf tempo trainer valid untuk digunakan dengan nilai $\mathrm{r}_{\mathrm{xy}}=0.7096$, nilai ini lebih dari nilai $r$ tabel $=0.632$. Dari analisis uji reliabilitas diperoleh nilai $r_{x y}=0.826$, nilai ini lebih dari 0.60, dengan demikian dapat dikatakan bahwa draf tempo trainer reliabel.

Berdasarkan penilaian pelatih renang ditunjukkan bahwa total nilai, uji validitas dan reliabilitas draf tempo trainer telah memenuhi persyaratan kelayakan untuk uji coba skala besar.

Setelah selesai dilakukan revisi draf tempo trainer yang diujicobakan pada skala kecil, ditindaklanjuti dengan melakukan uji coba lapangan skala besar. Uji coba skala besar dilaksanakan di lima perkumpulan renang yaitu Tirta Alvita, Yuso, Dolphin, Caesar, dan Arwana dengan jumlah 10 pelatih dan 25 atlet. Data hasil uji coba skala besar adalah sebagai berikut:

Tabel 17. Penilaian Observasi Ahli Renang pada Uji Coba Skala Besar

\begin{tabular}{|c|c|c|}
\hline Interval & Kategori & Total Skor \\
\hline$<32,66$ & Kurang & - \\
\hline$\geq 32,66$ s.d $<51,33$ & Cukup & - \\
\hline$\geq 51,33$ & Baik & 68,5 \\
\hline
\end{tabular}

menunjukkan total nilai terletak pada interval $\geq 51,33$. Berdasarkan penilaian tersebut draf tempo trainer berkategori baik.

Tabel 18. Penilaian Observasi Ahli Mikrokontroler pada Uji Coba Skala Besar

\begin{tabular}{ccc}
\hline Interval & Kategori & Total Skor \\
\hline$<21$ & Kurang & - \\
$\geq 21$ s.d $<33$ & Cukup & - \\
$\geq 33$ & Baik & 44 \\
\hline
\end{tabular}

Tabel penilaian observasi tersebut menunjukkan bahwa total nilai terletak pada interval $\geq 33$. Berdasarkan penilaian tersebut draf Tempo Trainer berkategori baik.

Tabel 19. Penilaian Observasi Pelatih pada Uji Coba Skala Besar

\begin{tabular}{ccc}
\hline Interval & Kategori & Total Skor \\
\hline$<46,67$ & Kurang & - \\
$\geq 46,67$ s.d $<93,33$ & Cukup & - \\
$\geq 93,33$ & Baik & 131 \\
\hline
\end{tabular}

Tabel penilaian observasi pelatih renang pada uji coba skala kecil menunjukkan bahwa total nilai yang diperoleh terletak pada interval $\geq 93,33$ sehingga berkategori baik.

Berdasarkan uji validitas dan reliabilitas diperoleh hasil bahwa draf tempo trainer valid untuk digunakan dengan nilai $r_{x y}=0.795$, nilai ini lebih dari nilai $r$ tabel $=0.632$. Dari analisis uji reliabilitas diperoleh nilai $r_{x y}=0.908$, nilai ini lebih dari 0.60, dengan demikian dapat dikatakan bahwa draf tempo trainer reliabel.

Tabel 20. Penilaian Atlet pada Uji Coba Skala Besar

\begin{tabular}{ccc}
\hline Interval & Kategori & Total Skor \\
\hline$<50$ & Kurang & - \\
$\geq 50$ s.d $<100$ & Cukup & - \\
$\geq 100$ & Baik & 142 \\
\hline
\end{tabular}

Tabel penilaian atlet terhadap draf tempo trainer pada uji coba skala besar menunjukkan bahwa total nilai yang diperoleh terletak pada interval $\geq 100$, sehingga berkategori baik.

Berdasarkan uji validitas dan reliabilitas menggunakan bantuan Microsoft Excell 2007, diperoleh hasil bahwa draf tempo trainer valid untuk digunakan dengan nilai $r_{x y}=0.513$, nilai ini lebih dari nilai $r$ tabel $=0.396$. Dari analisis uji reliabilitas diperoleh nilai $r_{x y}=0.750$, nilai ini lebih dari 0.60, dengan demikian dapat dikatakan bahwa draf tempo trainer reliabel.

\section{SIMPULAN}

Produk akhir penelitian ini menghasilkan alat tempo trainer untuk membantu efisiensi gerakan lengan gaya bebas pada cabang 


\section{Jurnal Keolahragaan 5 (2), September 2017 - 131 \\ Bahtiyar Heru Susanto}

olahraga renang. Hasil perhitungan normatif dan kategorisasi menunjukkan bahwa alat tempo trainer yang dikembangkan berkategori baik dan efektif dalam membantu efisiensi gerakan lengan gaya bebas. Hasil perhitungan tersebut didukung dengan uji validitas dan reliabilitas alat yang menunjukkan hasil valid dan reliabel. Penilaian draf alat tempo trainer oleh pelatih menunjukkan hasil valid dengan hasil setiap indikator PIECES (performance, information, economic, control, efficiency, service) memperoleh nilai $r_{x y}>r$ tabel $=0.632$, reliabel dengan hasil nilai $r=0.908$. Penilaian draf alat tempo trainer oleh atlet renang berkategori baik, valid dengan hasil nilai $r_{x y}>r$ tabel $=0.750$.

Produk akhir alat tempo trainer yang dikembangkan berkategori baik sehingga alat tempo trainer yang dikembangkan dapat menghitung siklus gerakan lengan gaya bebas, suara yang dihasilkan alat tempo trainer dapat didengar oleh pelatih maupun atlet yang sedang berenang, alat tempo trainer yang dikembangkan bisa digunakan untuk lebih dari satu atlet, dan harga alat tempo trainer yang dikembangkan lebih terjangkau.

\section{DAFTAR PUSTAKA}

Al Fatta, H. (2007). Analisis dan perancangan sistem informasi untuk keunggulan perusahaan dan organisasi kelas dunia. Yogyakarta: Stimik Akakom.

Andrianto, H. (2008). Pemrograman mikrokontroler AVR ATMega16. Bandung: Informatika.

Azwar, S. (2003). Penyusunan skala psikologi. Yogyakarta : Pustaka Pelajar . https://doi.org/2003

Bompa, T. O. (1999). Periodization: Theory and methodology of training. Champaign, United States: Human Kinetics.

Falaahudin, A., \& Sugiyanto, F. (2013). Evaluasi program pembinaan renang di klub Tirta Serayu, TCS, Bumi Pala, Dezender, Spectrum di Provinsi Jawa Tengah. Jurnal Keolahragaan, 1(1), 1325. https://doi.org/10.21831/JK.V1I1.2342

Fox, E. L., Bowers, R. W., Foss, M. L., \& Fox, E. L. (1993). The physiological basis for exercise and sport. Iowa: Brown \& Benchmark Publishers. Retrieved from https://www.goodreads.com/book/show/2 872497-the-physiological-basis-forexercise-and-sport
Gall, M. D., Gall, J. P., \& Borg, W. R. (2007). Educational research: An introduction. Boston: Pearson/Allyn \& Bacon.

Greco, C. C., Pelarigo, J. G., Figueira, T. R., \& Denadai, B. S. (2007). Effects of gender on stroke rates, critical speed and velocity of a 30-min swim in young swimmers. Journal of Sports Science \& Medicine, 6(4), 441.

Hannula, D. (2008). Sukses melatih renang. Yogyakarta: Pustaka Insan Madani. Retrieved from http://digilib.usu.ac.id/buku/88107/Sukses -melatih-renang.html

Irianto, D. P. (2004). Pedoman praktis berolahraga untuk kebugaran dan kesehatan. Yogyakarta: Andi Offset.

Kolmogorov, S. V, \& Duplishcheva, O. A. (1992). Active drag, useful mechanical power output and hydrodynamic force coefficient in different swimming strokes at maximal velocity. Journal of Biomechanics, 25(3), 311-8. https://doi.org/10.1016/00219290(92)90028-Y

Laughlin, T. (2001). Swimming made easy: The total immersion way for any swimmer to achieve fluency, ease, and speed in any stroke. New Paltz, NY: Swimware, Inc.

Maglischo, E. W. (2003). Swimming fastest. Human Kinetics.

Mandzak, P. dkk. (2010). Qualitative appraisal of freestyle technique of physical education students at department of physical education and sport in Banska Bystrica. In Analysis of sports for children and youth. Ljubljana: Faculty of Sports University of Ljubljana. ISBN 978-961-6583-84-8., pp. 83-90.

Mandzák, P., \& Stankiewicz, B. (2014). Correction of errors front crawl swimming technique of students of physical education and sport. Journal of Health Sciences, 4(14), 27-38. https://doi.org/10.5281/ZENODO.13262

Smith, J. (2012). The use of streamlining, cycle counting, tempo, tempo trainers strategies with competitive swimmers: A case series. Journal of the international society of swimming coaching. Vol 2, Issue 1.

Sugiyono. (2010). Metode penelitian kuantitatif kualitatif dan $R \& D$. Bandung: Alfabeta. 
Jurnal Keolahragaan 5 (2), September 2017 - 132

Bahtiyar Heru Susanto

Suharjana, S. (2007). Latihan beban: Sebuah metode latihan kekuatan. Medikora: Jurnal Iimiah Kesehatan Olahraga, 3(2). Retrieved from https://journal.uny.ac.id/index.php/medik ora/article/view/4719

Sukadiyanto \& Muluk, D. (2011). Pengantar teori dan metodologi melatih fisik. Bandung: Lubuk Agung.

Winoto, A. (2010). Mikrokontroler AVR ATMEGA 8/16/32/8535, dan

Pemrograman dengan Bahasa $C$. Yogyakarta: Andi. 